\title{
Effects of enzyme feeding strategy on ethanol yield in fed-batch simultaneous saccharification and fermentation of spruce at high dry matter
}

\author{
Kerstin Hoyer*, Mats Galbe and Guido Zacchi
}

\begin{abstract}
Background: To make lignocellulosic fuel ethanol economically competitive with fossil fuels, it is necessary to reduce the production cost. One way to achieve this is by increasing the substrate concentration in the production process, and thus reduce the energy demand in the final distillation of the fermentation broth. However, increased substrate concentration in simultaneous saccharification and fermentation (SSF) processes has been shown to result in reduced ethanol yields and severe stirring problems. Because the SSF medium is being continuously hydrolyzed, running the process in fed-batch mode could potentially reduce the stirring problems and lead to increased ethanol yields in highsolids SSF. Different enzyme feeding strategies, with the enzymes either present in the reactor from start-up or fed into the reactor together with the substrate, have been studied, along with the influence of the enzyme feeding strategy on the final ethanol yield and productivity.
\end{abstract}

Results: In the present study, SSF was run successfully with 10\% and 14\% water-insoluble solids (WIS) in batch and fedbatch mode. The mixing of the material in the reactor was significantly better in fed-batch than batch mode, and similarly high or higher ethanol yields were achieved in fed-batch mode compared with batch SSF in some cases. No general trend in the dependence of ethanol yield on enzyme feeding strategy was found.

Conclusions: The optimum enzyme feeding strategy appears to depend on the conditions during SSF, such as the WIS concentration and the concentration of inhibitory compounds in the SSF medium.

\section{Background}

Climate change is one of the greatest challenges of our time. Replacing fossil fuels with so-called biofuels, such as bioethanol, is one way of reducing greenhouse gas emissions from the transport sector, which is responsible for a considerable proportion of total $\mathrm{CO}_{2}$ emissions [1]. Currently, many crops rich in sugar or starch, such as sugarcane, maize and wheat, are used for ethanol production. However, to minimize the environmental effects and the competition between crops for food and fuel production, and to maximize cost efficiency, it is important to consider other raw materials. So-called 'second-generation bioethanol production', using lignocellulosic material such as agricultural or wood residues, is considered a promising approach. In Sweden, the most abundant raw

* Correspondence: kerstin.hoyer@chemeng.lth.se

${ }^{1}$ Department of Chemical Engineering, Lund University, PO Box 124, SE-221 00 Lund, Sweden

Full list of author information is available at the end of the article material for ethanol production is softwood, in the form of logging waste and waste from the forest industry [2].

Bioethanol can be produced from lignocellulosic material by hydrolysis of the cellulose and hemicellulose to monomeric sugars, followed by fermentation of these sugars to ethanol [1,3]. Performing hydrolysis and fermentation in a single step, the so-called 'simultaneous saccharification and fermentation' (SSF) process, has several advantages over separate saccharification and fermentation (SHF) [4-6]. In SSF, end-product inhibition of $\beta$-glucosidase is avoided, and the number of reactors needed in the process is reduced $[4,7,8]$. Furthermore, SSF has been shown to be superior to SHF in terms of overall ethanol yield [9-11].

Before beginning SSF, the raw material needs to be pretreated to break down the hemicellulose and make the cellulose more accessible to the enzymes used in the hydrolysis (Figure 1). Steam explosion using $\mathrm{SO}_{2}$ as a catalyst has been shown to be successful for softwood and 


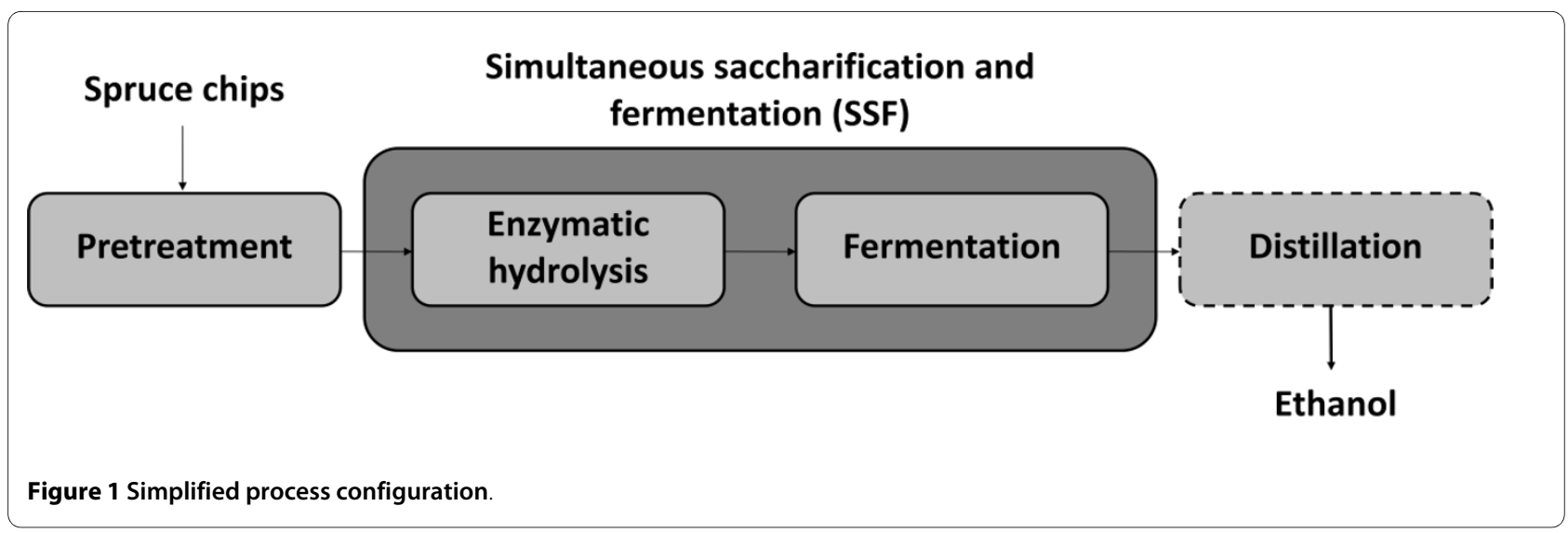

other lignocellulosic materials [2,12-18]. This results in a solid fraction containing mostly cellulose and lignin, and a hydrolysate containing monomeric sugars derived from the hemicellulose, with small amounts of other carbohydrates, sugar and lignin degradation products, acetic acid, and other compounds [19]. Some of these compounds have been found to be inhibitory to enzymatic hydrolysis [14,20-22] and fermentation [19,21,23-26].

To make ethanol an economically competitive alternative to fossil fuel, it is necessary to reduce the production cost. Recovery of ethanol from the fermentation broth by distillation is one of the most energy-intensive steps in the wood to ethanol conversion process $[7,8]$. Major cost savings could thus be achieved by reducing the energy demand in the distillation step. Because the cost of distil- lation decreases as the ethanol concentration in the distillation feed increases [8], it is important to reach the highest possible ethanol concentration in the SSF step [7]. One way of achieving this is by increasing the substrate concentration in SSF. Previous studies have shown high ethanol yields in SSF using 5\% water-insoluble solids (WIS) $[9,27,28]$; however, studies with higher dry matter (DM) content have shown a decrease in ethanol yield [9,27-29].

One reason for the decrease in ethanol yield at higher DM content is difficulty in stirring [29], which can be overcome by running SSF in fed-batch mode, as the fibers will then be continuously degraded, reducing the viscosity of the fermentation medium compared with batch SSF. Another advantage of fed-batch SSF over batch SSF

Table 1: Summary of the experiments performed

\begin{tabular}{|c|c|c|c|c|c|}
\hline Experiment & WIS, \% & Batch of pretreated material & $\begin{array}{c}\text { Mode of } \\
\text { SSF }\end{array}$ & Type of slurry in batch & WIS of feed, $\%$ \\
\hline $1 \mathrm{~A}$ & 10 & 1 & Batch & Whole, pressed slurry & - \\
\hline $1 \mathrm{~B}$ & $6-10$ & 1 & Fed-batch & Whole slurry & 29.5 \\
\hline $1 C$ & $6-10$ & 1 & Fed-batch & Whole slurry & $29.5^{\mathrm{a}}$ \\
\hline $1 \mathrm{D}$ & $6-10$ & 1 & Fed-batch & Whole slurry & $29.5^{\mathrm{a}}$ \\
\hline $2 \mathrm{~A}$ & 14 & 2 & Batch & Whole, pressed slurry & - \\
\hline $2 B$ & $9-14$ & 2 & Fed-batch & Whole slurry & 24.1 \\
\hline $2 \mathrm{C}$ & $9-14$ & 2 & Fed-batch & Whole slurry & $24.1^{\mathrm{a}}$ \\
\hline $2 \mathrm{D}$ & $9-14$ & 2 & Fed-batch & Whole slurry & $24.1^{\mathrm{a}}$ \\
\hline $3 \mathrm{~A}$ & 14 & 2 & Batch & Whole, pressed slurry & - \\
\hline 3B & $9-14$ & 2 & Fed-batch & Whole, pressed slurry & 23.6 \\
\hline $3 C$ & $9-14$ & 2 & Fed-batch & Whole, pressed slurry & $23.6^{a}$ \\
\hline $3 \mathrm{D}$ & $9-14$ & 2 & Fed-batch & Whole, pressed slurry & $23.6^{a}$ \\
\hline $4 \mathrm{~A}$ & 14 & 2 & Batch & Washed, pressed slurry & - \\
\hline $4 B$ & $9-14$ & 2 & Fed-batch & Washed, pressed slurry & 19.9 \\
\hline $4 C$ & $9-14$ & 2 & Fed-batch & Washed, pressed slurry & $19.9^{a}$ \\
\hline
\end{tabular}

alncluding enzymes. 


\section{A. Batch (reference)}

Substrate
Enzymes
Nutrients
Yeast

\section{Fed-batch: enzyme addition distributed between batch and substrate feed, mixed at start-up}

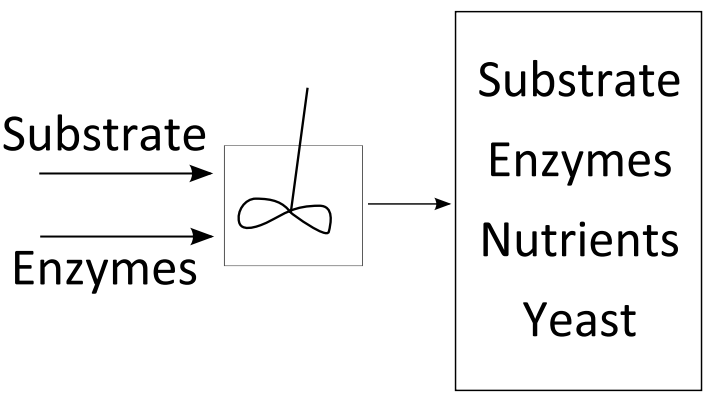

Figure 2 The four enzyme feeding strategies investigated.

is the lower concentrations of inhibitory compounds, as all the hydrolysate is not added at the same time [30]. This also gives the yeast a chance to convert some of the inhibitory compounds into compounds with lower inhibition, and thus 'detoxify' the fermentation medium $[22,31,32]$. Furthermore, for feedstocks rich in pentose sugars, it has been shown that higher conversion of both pentose and hexose sugars to ethanol can be achieved when keeping the glucose level low in the fermentation medium [33], which can be achieved in fed-batch SSF $[33,34]$.

To our knowledge, the effects on overall ethanol yield and enzyme consumption of different methods of adding the enzymes to fed-batch SSF have not been studied. The aim of this study was therefore to investigate the effects of

\section{B. Fed-batch: all enzymes added to the fermentor at start-up}

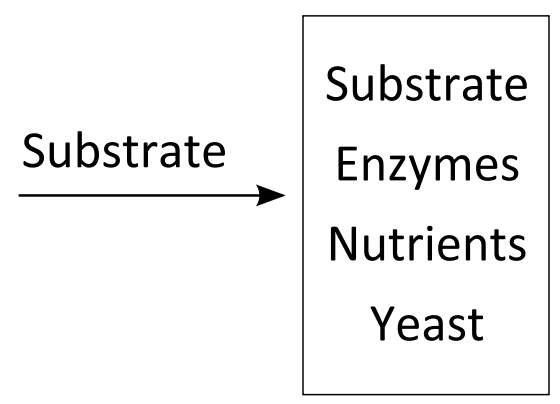

\section{Fed-batch: enzyme addition distributed between batch and substrate feed, added separate from substrate}

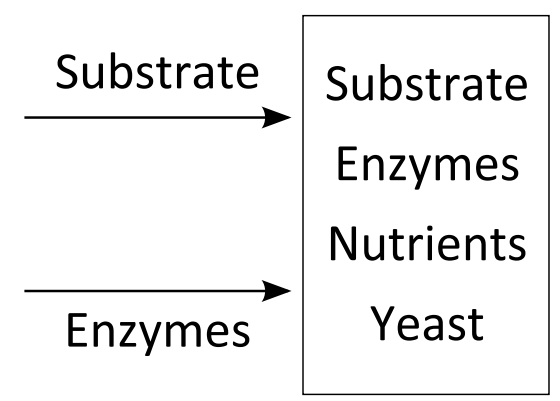

different enzyme feeding strategies to optimize the SSF process for ethanol production.

\section{Methods}

\section{Raw material}

Spruce was kindly provided by a sawmill in Southern Sweden (Widtsköfle Sågverk AB, Degeberga, Sweden). The wood was chipped at a knife mill (Retsch $\mathrm{GmbH}$, Haan, Germany) and sieved to obtain a chip size of 2-10 $\mathrm{mm}$. The chips were stored in a plastic bag at $4^{\circ} \mathrm{C}$ before use. The same batch of raw material was used for all experiments.

\section{Steam pretreatment}

The softwood chips were impregnated with $\mathrm{SO}_{2}(2 \% \mathrm{w} / \mathrm{w}$ moisture) for $20 \mathrm{~min}$ at room temperature, in tightly 
Table 2: Composition of the raw material (spruce) and the washed fibers from the two batches of pretreated slurry

\begin{tabular}{llll}
\hline Component & $\begin{array}{l}\text { Amount, \% of dry matter } \\
\text { Raw material }\end{array}$ & Washed pretreated material & \\
& & Batch 1 & Batch 2 \\
\hline Glucan & $44.9 \pm 0.1$ & $46.7 \pm 1.5$ & $53.4 \pm 0.4$ \\
Mannan & $12.0 \pm 0.0$ & $1.9 \pm 0.3$ & $0.7 \pm 0.0$ \\
Xylan & $5.2 \pm 0.0$ & $1.6 \pm 0.1$ & $0.4 \pm 0.0$ \\
Galactan & $2.2 \pm 0.0$ & $1.2 \pm 0.1$ & $0.1 \pm 0.0$ \\
Arabinan & $2.0 \pm 0.0$ & $1.2 \pm 0.0$ & $0.0 \pm 0.0$ \\
Lignin & $31.1 \pm 1.2$ & $44.9 \pm 2.6$ & $45.3 \pm 0.2$ \\
\hline
\end{tabular}

sealed plastic bags. The amount of $\mathrm{SO}_{2}$ absorbed was determined by weighing the plastic bags and their contents before and after impregnation.

The impregnated softwood was pretreated in a steam pretreatment unit equipped with a $10 \mathrm{~L}$ reactor, as previously described by Palmqvist et al. [35]. All steam pretreatment experiments were performed at $210^{\circ} \mathrm{C}$ for 5 min, as these had previously been determined to be the optimal pretreatment conditions for high yield of fermentable sugars in enzymatic hydrolysis and high yield of ethanol in subsequent fermentation [36]. When the desired pretreatment time had elapsed, the pressure was released and the material collected in a tank. Owing to the limited size of the reactor, the impregnated softwood was pretreated in batches of $700 \mathrm{~g}$ DM. The slurries obtained were mixed to form one large batch. Two different batches were pretreated on different occasions (hereafter referred to as batch 1 and batch 2). The pretreated slurry was stored at $4^{\circ} \mathrm{C}$ before subsequent analysis and use in SSF.

\section{Cell cultivation Inoculum}

The inoculum culture was prepared on an agar plate containing pure baker's yeast (Saccharomyces cerevisiae), purified from compressed baker's yeast (Jästbolaget, Rotebo, Sweden). The cells were added to a $300 \mathrm{~mL}$ Erlenmeyer flask together with $70 \mathrm{~mL}$ of an aqueous solution containing $23.8 \mathrm{~g} / \mathrm{L}$ glucose, $10.8 \mathrm{~g} / \mathrm{L}\left(\mathrm{NH}_{4}\right)_{2} \mathrm{SO}_{4}, 5.0$ $\mathrm{g} / \mathrm{L} \mathrm{KH}_{2} \mathrm{PO}_{4}$ and $1.1 \mathrm{~g} / \mathrm{L} \mathrm{MgSO}_{4} 7 \mathrm{H}_{2} \mathrm{O}$. The solution also contained $14.4 \mathrm{~g} / \mathrm{L}$ trace metal solution and $1.4 \mathrm{~g} / \mathrm{L}$ vitamin solution, prepared as described by Taherzadeh et al. [37]. The $\mathrm{pH}$ was adjusted to 5 with $0.25 \mathrm{M} \mathrm{NaOH}$, and the Erlenmeyer flask was sealed with a cotton plug and incubated at $30^{\circ} \mathrm{C}$ for $19-24 \mathrm{~h}$ on a rotary shaker.

\section{Aerobic cultivation}

The aerobic cell cultivation was performed in two steps. The cells were first cultivated in batch mode on a glucose solution, after which the mode was changed to fed-batch with a feed that contained hydrolysate liquid from the

Table 3: Composition of the liquid fraction of the two batches of pretreated material

\begin{tabular}{lll}
\hline Component & Concentration, g/L & Batch 2 \\
& Batch $\mathbf{1}$ & $27.1 \pm 0.1(42.1)^{\mathrm{a}}$ \\
\hline Glucose & $13.3 \pm 0.8(91.7)^{\mathrm{a}}$ & $28.7 \pm 0.1(41.7)^{\mathrm{a}}$ \\
Mannose & $22.1 \pm 2.0(88.3)^{\mathrm{a}}$ & $11.4 \pm 0.0(47.5)^{\mathrm{a}}$ \\
Xylose & $8.6 \pm 0.8(101.5)^{\mathrm{a}}$ & $4.5 \pm 0.0(42.0)^{\mathrm{a}}$ \\
Galactose & $3.6 \pm 0.1(89.0)^{\mathrm{a}}$ & $\mathrm{ND}$ \\
Arabinose & $\mathrm{ND}$ & $2.72 \pm 0.0$ \\
HMF & $1.93 \pm 0.0$ & $1.16 \pm 0.0$ \\
Furfural & $0.85 \pm 0.0$ & $4.75 \pm 0.0$ \\
Lactic acid & $3.80 \pm 0.0$ & $5.87 \pm 0.0$ \\
Acetic acid & $4.92 \pm 0.0$ & \\
\hline
\end{tabular}

$\mathrm{HMF}=5$-hydroxymethylfurfural; ND = not done.

Data are mean values \pm SD unless otherwise indicated.

aMean value $\pm S D$, the percentage of sugars in monomeric form compared with total sugars is given in brackets. 


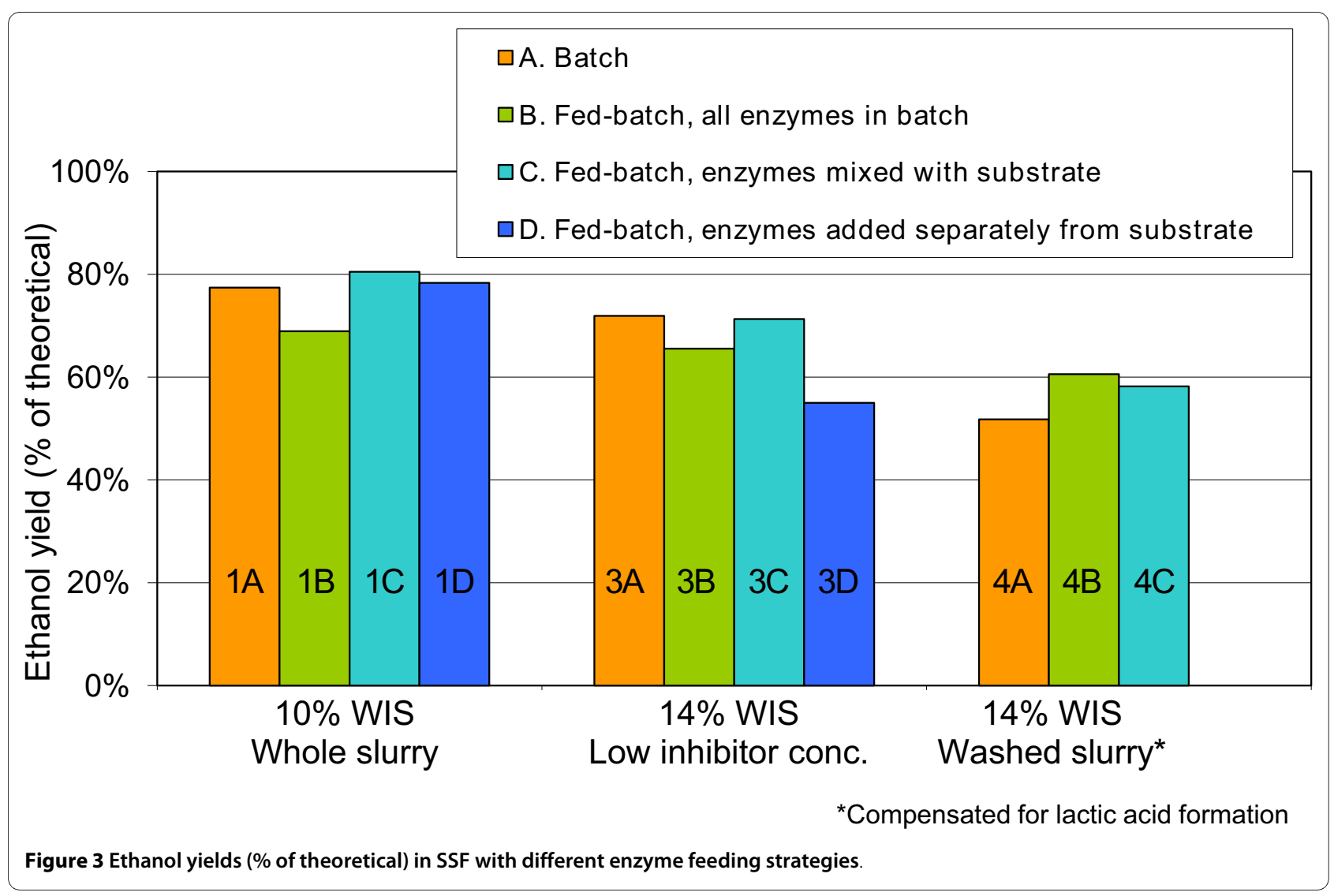

pretreatment step. Adapting the yeast cells to pretreatment hydrolysate has previously been shown to make the yeast more resistant to the inhibitors in the fermentation medium and thus give higher ethanol yields in SSF, especially at higher DM contents [38]. Both steps were performed in a $2 \mathrm{~L}$ fermentor (Infors AG, Bottmingen, Switzerland) at $30^{\circ} \mathrm{C}$. The $\mathrm{pH}$ was continuously adjusted to 5 by the addition of $2.5 \mathrm{M} \mathrm{NaOH}$ throughout the cell cultivation process.

The working volume for batch cultivation was $500 \mathrm{~mL}$, and the medium contained $20.0 \mathrm{~g} / \mathrm{L}$ glucose, $22.5 \mathrm{~g} / \mathrm{L}$ $\left(\mathrm{NH}_{4}\right)_{2} \mathrm{SO}_{4}, 10.5 \mathrm{~g} / \mathrm{L} \mathrm{KH}_{2} \mathrm{PO}_{4}$ and $2.2 \mathrm{~g} / \mathrm{L} \mathrm{MgSO} \mathrm{MH}_{4} \mathrm{O}$, $60 \mathrm{~g} / \mathrm{L}$ trace metal solution and $6.0 \mathrm{~g} / \mathrm{L}$ vitamin solution. Cultivation was started by adding $60 \mathrm{ml}$ inoculum. Batch cultivation was performed at a stirrer speed of $700 \mathrm{rpm}$. The fermentor was aerated, and the air flow was adjusted to ensure a concentration of dissolved oxygen of $>5 \%$ at all times.

Once the concentration of dissolved oxygen increased rapidly, indicating that all the ethanol produced during batch cultivation had been depleted, batch cultivation was changed to fed-batch cultivation. This occurred 2122 hours after start of the aerobic batch cultivation in the various cultivation batches. Fed-batch cultivation was performed with hydrolysate from the pretreatment step. A total volume of $1 \mathrm{~L}$ feed containing hydrolysate supplemented with glucose and salt solution, to give a feed con- centrations of $80 \mathrm{~g} / \mathrm{L}$ glucose, $11.3 \mathrm{~g} / \mathrm{L}\left(\mathrm{NH}_{4}\right)_{2} \mathrm{SO}_{4}, 5.3 \mathrm{~g} / \mathrm{L}$ $\mathrm{KH}_{2} \mathrm{PO}_{4}$ and $1.1 \mathrm{~g} / \mathrm{L} \mathrm{MgSO}_{4} 7 \mathrm{H}_{2} \mathrm{O}$, was added over a period of 16-24 hours. The final concentration of hydrolysate in the fermentor was equivalent to that which would have been obtained if the slurry from pretreatment had been diluted to $7.5 \%$ WIS. Fed-batch cultivation was performed in the aerated fermentor at a stirrer speed of $1000 \mathrm{rpm}$.

\section{Cell harvest}

The cultivation medium was centrifuged in $750 \mathrm{~mL}$ containers at $3500 \mathrm{rpm}$ for 5 min (Jouan C4-12 centrifuge, St Herblain, France). The time elapsed between cell harvest and the addition of the cells to SSF was $<2 \mathrm{~h}$.

\section{SSF}

All SSF experiments were performed in $2 \mathrm{~L}$ fermentors (Infors AG, Bottmingen, Switzerland) for 120 hours, with a working weight of $1.3 \mathrm{~kg}$. The temperature in the reactor was maintained at $37^{\circ} \mathrm{C}$, and the $\mathrm{pH}$ was continuously adjusted to 5 with $2.5 \mathrm{M} \mathrm{NaOH}$. In the batch experiments, the diluted slurry was autoclaved at $121^{\circ} \mathrm{C}$ for 20 min. In the fed-batch experiments, the slurry in the fermentor at start-up was autoclaved in the same way, whereas the substrate feed was not autoclaved. The substrate intended for the feed was pressed (Tinkturenpresse HP-5M, Fischer Maschinenfabrik GmbH, Neuss, Germany) to the WIS concentrations given in Table 1. Nutri- 


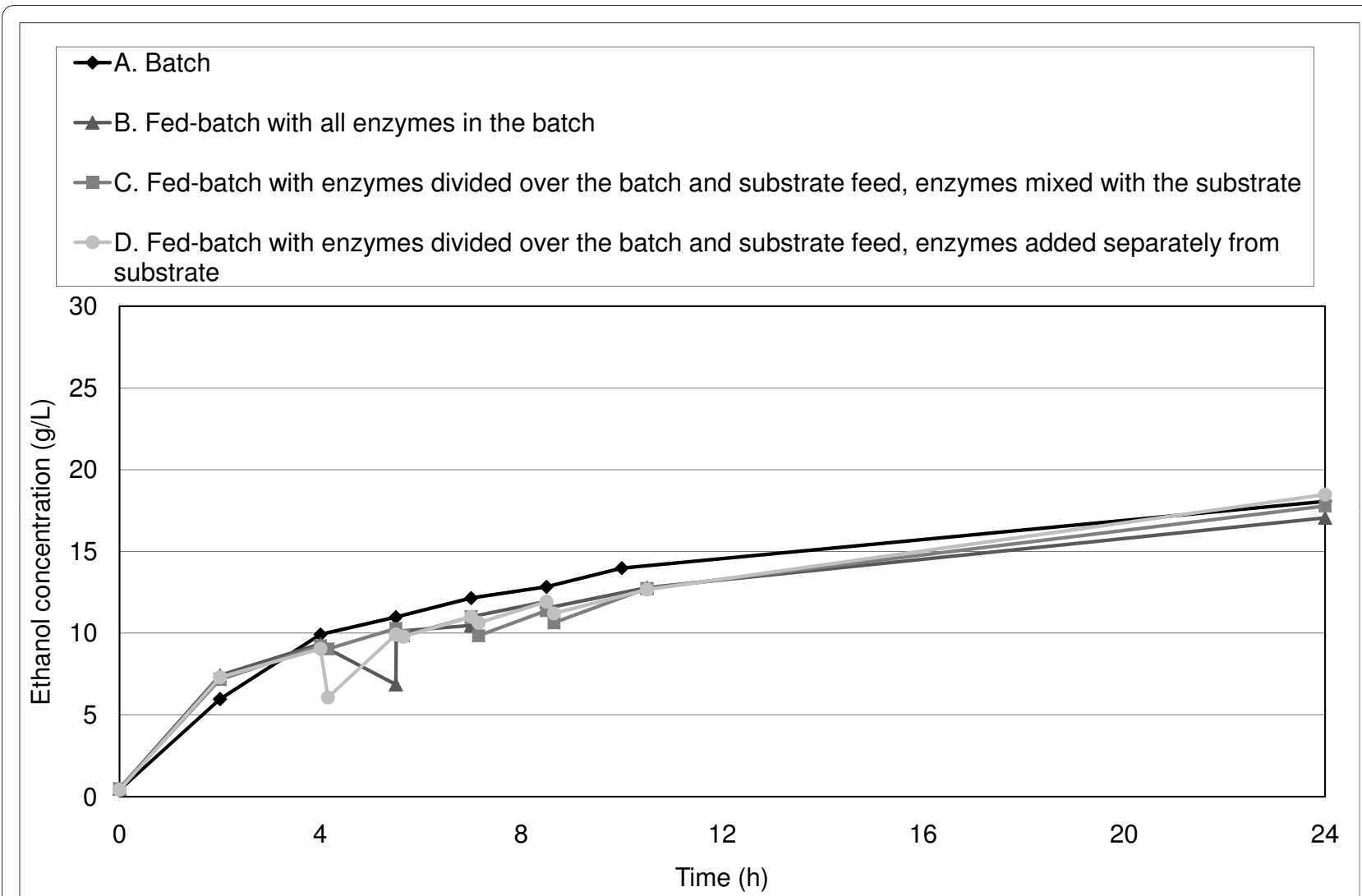

Figure 4 Ethanol concentration in SSF with a final WIS content of $10 \%$ and whole slurry during the first 24 hours.

ents were mixed together, sterilized and added to the reactor to give final concentrations of $0.5 \mathrm{~g} / \mathrm{L}$ $\left(\mathrm{NH}_{2}\right)_{2} \mathrm{HPO}_{4}, 0.025 \mathrm{~g} / \mathrm{L} \mathrm{MgSO}{ }_{4} 7 \mathrm{H}_{2} \mathrm{O}$ and $1.0 \mathrm{~g} / \mathrm{L}$ yeast extract. The SSF experiments were performed with a yeast cell concentration of $5 \mathrm{~g}$ dry yeast cells $/ \mathrm{kg}$ final working weight. A commercial cellulase mixture was used, consisting of a cellulase derived from Trichoderma reesei (Celluclast 1.5L; Novozymes A/S, Bagsværd, Denmark) (57.8 filter-paper units (FPU)/g and 38 IU/g) supplemented with a $\beta$-glucosidase preparation (Novozyme 188; Novozymes A/S) (503 $\beta$-glucosidase IU/g). The level of enzymes added corresponded to a total cellulase activity of $5 \mathrm{FPU} / \mathrm{g}$ WIS and a total $\beta$-glucosidase activity of 8 IU/g WIS.

The following enzyme feeding strategies were investigated.

(A) Batch SSF (reference) (Figure 2A).

(B) Fed-batch SSF with all enzymes added to the fermentor at start-up. To make this comparable with feeding strategies (C) and (D), water equal to the amount of enzyme solution added with the feed in (C) and (D) was mixed with the substrate feed (Figure 2B).

(C) Fed-batch SSF with enzymes divided between the batch and substrate feed according to the WIS content in these. The enzymes were mixed with the substrate feed at start-up (Figure 2C).
(D) As in (C) above, but with the difference that the enzymes were added at the same time as the substrate feed but were not mixed with the substrate before addition to the reactor (Figure 2D).

In fed-batch SSF, the feed was added manually in four equally sized portions at 4, 5.5, 7 and 8.5 hours after startup, as early addition of substrate has been shown to give better results than late addition [33,39]. Experimental series were run at final WIS concentrations of $10 \%$ and $14 \%$ (in fed-batch mode starting with $6 \%$ and $9 \%$ WIS, respectively). Runs with $10 \%$ WIS were performed on whole pretreated slurry (SSF 1A to 1D in Table 1). Runs with $14 \%$ WIS were performed on whole pretreated slurry (SSF 2A to 2D in Table 1), on slurry with 20\% lower inhibitor concentration (obtained by replacing part of the hydrolysate with water) (SSF 3A to 3D in Table 1) and on washed slurry (SSF $4 \mathrm{~A}$ to $4 \mathrm{C}$ in Table 1) (obtained by diluting and washing with excess water several times).

\section{Analysis}

All analyses were performed in duplicate. DM content was determined by drying the samples in an oven at $105^{\circ} \mathrm{C}$ until a constant weight was obtained. The composition of the spruce and of the washed solids from the pretreated slurry was determined according to the National Renewable Energy Laboratory (NREL) proce- 


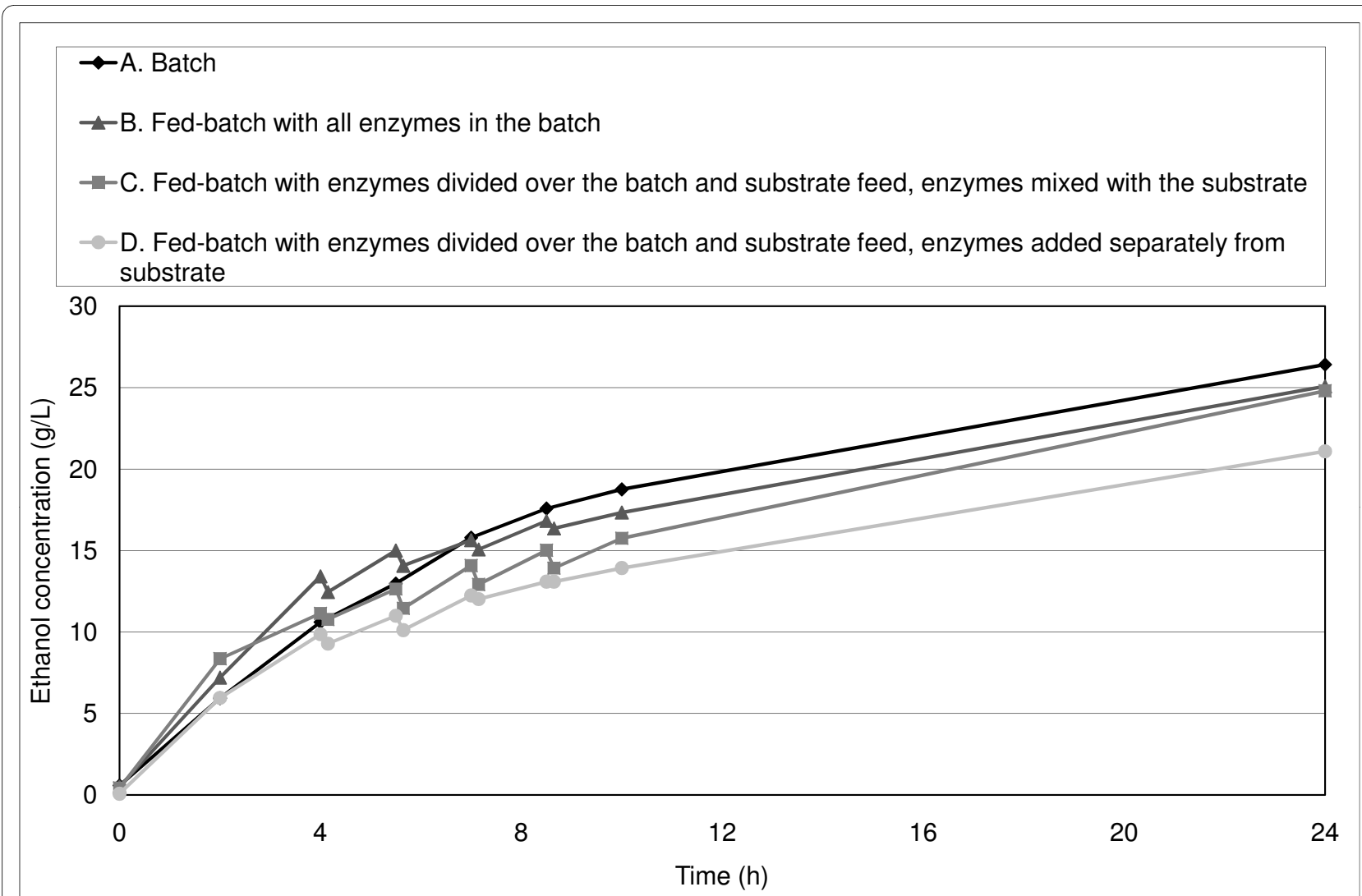

Figure 5 Ethanol concentration in SSF with a final WIS content of $14 \%$ and low inhibitor concentration during the first 24 hours.

dure for the determination of structural carbohydrates and lignin in biomass [40]. The solids used for analysis were separated from the liquid fraction of the pretreated slurry by filtration and washed with excess water, making sure that the liquid fraction in the material was replaced several times during the washing process. The hydrolysate from the pretreated slurry was analyzed for its content of oligosaccharides using the NREL procedure for the determination of sugars, byproducts and degradation products in liquid fraction process samples [41]. The oligosaccharide concentration was determined as the difference in monomeric sugar concentration before and after acid hydrolysis.

Samples from analysis of the raw material and the washed solids, the hydrolysate of the pretreated slurry, and samples from SSF were analyzed for their content of monomeric sugars. All samples were filtered through a $0.2 \mu \mathrm{m}$ filter to remove particles before analysis. Analyses were carried out using a high-performance anionexchange chromatograph (HPAEC) coupled with pulsed amperometric detection (PAD) and an electrochemical detector (ED40; Dionex, Sunnyvale, CA, USA). A gradient pump (GP40), an autosampler (AS50), a guard column (Carbo Pac PA1) and an analytical column (PA10) (all Dionex) were used. The eluent was $2 \mathrm{mM} \mathrm{NaOH}$ at a flow rate of $1 \mathrm{~mL} / \mathrm{min}$, and the injection volume was 10 $\mu \mathrm{L}$.

The samples taken from the SSF experiments were also analyzed for their byproduct content (lactic acid, acetic acid, 5-hydroxymethylfurfural and furfural) and ethanol using high-performance liquid chromatography (HPLC), a refractive index detector (Shimadzu, Kyoto, Japan) and strong cation exchange resin column (Aminex HPX-87H; Bio-Rad Laboratories, Hercules, CA, USA) at $65^{\circ} \mathrm{C}$ with 5 $\mathrm{mM} \mathrm{H}_{2} \mathrm{SO}_{4}$ as eluent at a flow rate of $0.5 \mathrm{~mL} / \mathrm{min}$.

\section{Results}

Unless otherwise stated, the ethanol yield is given as the ethanol yield from the SSF step, and is expressed as a percentage of the theoretical yield, based on the contents of glucose and mannose in the pretreated material.

\section{Pretreatment}

The DM content of the wood chips before pretreatment was $48 \%$. After pretreatment, the slurries had a DM content of $13.3 \%$ (batch 1) and $16.0 \%$ (batch 2) WIS. The compositions of the raw material and the two pretreated batches are presented in Table 2 and Table 3. Most of the 


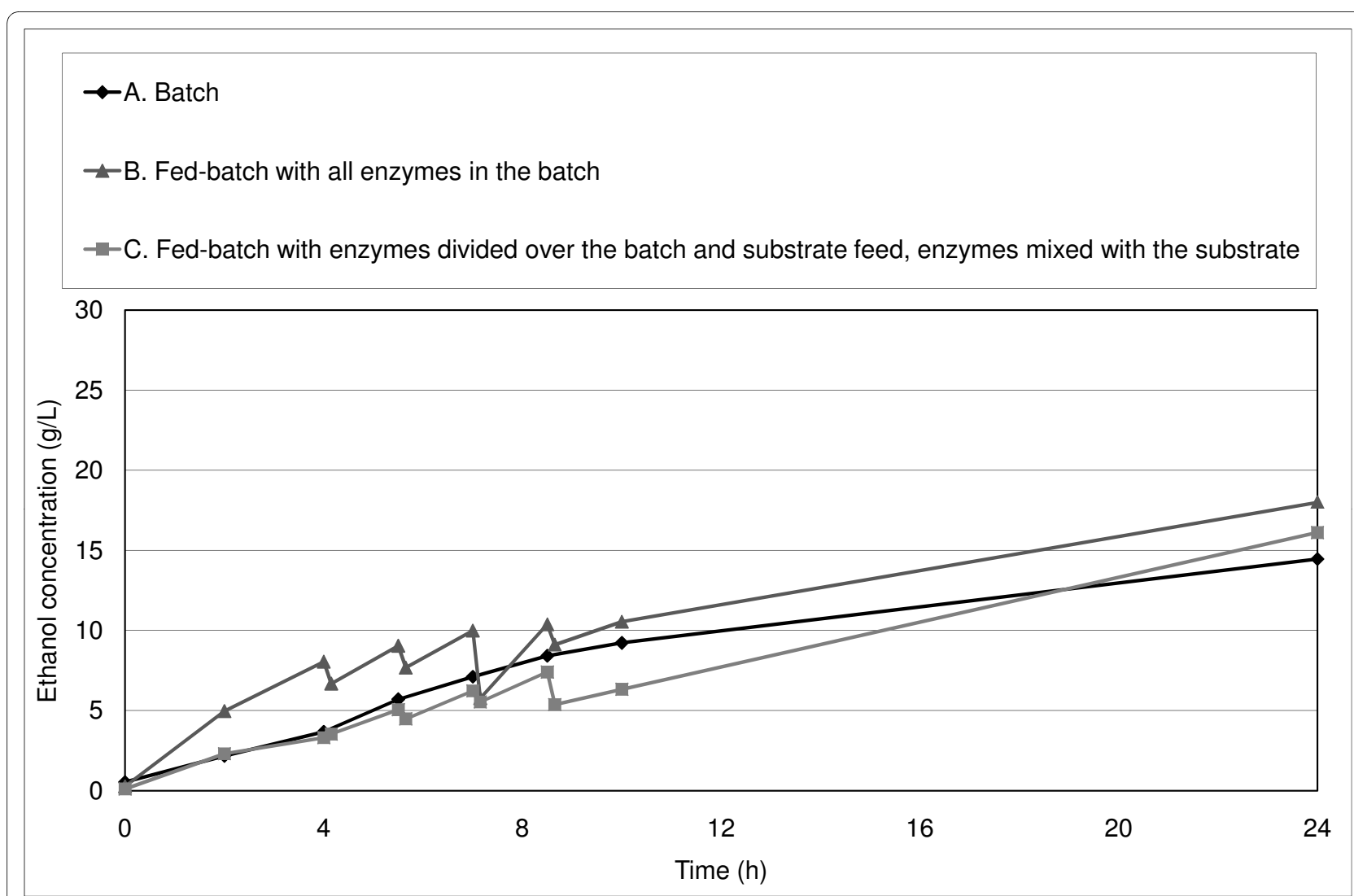

Figure 6 Ethanol concentration in SSF with a final WIS content of $14 \%$ and washed slurry during the first 24 hours (compensated for lactic acid formation).

differences in concentrations of sugars in the material of the two pretreated batches were due to different correction factors for sugar degradation in the experimental procedure used in the material analysis. This has no influence on the results of the study, as the same material was used within each experimental SSF series.

\section{SSF}

\section{Final WIS concentration of $10 \%$}

Batch SSF with 10\% WIS resulted in an ethanol yield of $77.4 \%$. Fed-batch SSF at this fiber concentration with all enzymes added in the batch phase at start-up (Table 1, SSF 1B) resulted in a lower ethanol yield (68.9\%). Adding part of the enzyme mix with the substrate feed in fedbatch SSF (Table 1, SSF 1C and 1D) resulted in slightly higher ethanol yields than the batch SSF, both when the enzymes were mixed with the substrate before addition to the fermentor and when they were added separately (Figure 3).

\section{Final WIS concentration $14 \%$}

Whole slurry Experiments with a final WIS content of $14 \%$ using whole pretreated slurry in SSF (Table 1, SSF 2A to $2 \mathrm{D})$ resulted in the accumulation of substantial amounts of glucose in the reactor (around $15 \mathrm{~g} / \mathrm{L}$ for SSF $2 \mathrm{~A}$ and $2 \mathrm{~B}$ and 35 and $45 \mathrm{~g} / \mathrm{L}$ for SSF $2 \mathrm{C}$ and $2 \mathrm{D}$ after 120 hours). These results were therefore not used for evaluation of the effect of the enzyme feeding strategy on the ethanol yield in fed-batch SSF.

Low inhibitor concentration SSF at a final WIS content of $14 \%$ and low inhibitor concentration resulted in a similar trend to that observed with a final WIS content of $10 \%$, with similar ethanol yields for batch SSF and fedbatch SSF when part of the enzyme mix was added with the substrate feed (mixed) and a slightly lower ethanol yield for fed-batch SSF when all the enzymes were added to the fermentor at start-up (Figure 3). In this case, fedbatch with enzyme feeding strategy ' $D$ ' (part of the enzymes added with the substrate feed, but separately from the substrate) resulted in a lower ethanol yield than both the batch and the other fed-batch experiments (Figure 3).

Washed slurry SSF at a final WIS content of $14 \%$ and washed slurry resulted in the formation of lactic acid, starting between 10 and 24 hours after start-up in all cases (Table 1, SSF 4A to 4C). The final lactic acid concentration after 120 hours was around $18 \mathrm{~g} / \mathrm{L}$ in all of these SSF runs. The ethanol yields for these SSF runs have been compensated for lactic acid formation, assuming that the sugars used for the observed lactic acid for- 
mation could instead have been converted to ethanol with 100\% yield. Batch SSF (Table 1, SSF 4A) resulted in an ethanol yield of $51.8 \%$. Both fed-batch SSF when all enzymes were added at start-up (Table 1, SSF 4B) and when part of the enzyme mix was added with the substrate feed (mixed with the substrate feed) (Table 1, SSF 4C) resulted in higher ethanol yields than batch SSF. The ethanol yield was slightly higher when all enzymes were added in the batch phase at start-up (Figure 3). Initial productivity

The initial ethanol productivity was equal or slightly higher in fed-batch SSF experiments than in batch SSF (Figure 4, Figure 5, Figure 6).

\section{Discussion}

Running SSF in fed-batch instead of batch mode greatly increased the mixing in the reactor, especially at the higher WIS concentration studied. Furthermore, in all cases, the enzyme feeding strategy had an effect on the ethanol yield in SSF. However, the enzyme feeding strategy resulting in the highest ethanol yield was different not only for the different substrate concentrations studied, but also for different inhibitor concentrations. One explanation of this could be the difference in the degree of deactivation of the enzymes in the different cases. In the experiments with hydrolysate present in the fermentor (Table 1, SSF $1 \mathrm{~A}$ to $1 \mathrm{D}$ and 3A to 3D), the enzymes might be partially deactivated by binding to compounds present in the hydrolysate, resulting in a lower quantity of enzymes being available to the fed substrate, thereby decreasing hydrolysis. In SSF with washed slurry (Table 1, SSF 4A-C), no hydrolysate is present in the fermentor, preventing enzyme deactivation by compounds present in the hydrolysate. Thus, if no deactivation of enzymes due to binding to compounds present in the hydrolysate occurs, the highest ethanol yield is obtained in fed-batch SSF when the greatest possible enzyme quantity is present in the fermentor for the longest possible time (Table 1 , SSF 4B).

When adding part of the enzyme mix together with the substrate feed, it appears to be advantageous to mix the enzymes with the substrate before addition to the reactor. This indicates that the hydrolysis of the substrate feed has already started before addition to the fermentor at room temperature, or that some of the enzymes added with the substrate feed adsorb to material already in the reactor, rather than to the fed substrate if they are added separate from the fed substrate.

Previous studies on fed-batch SSF have given different results. In some cases, fed-batch SSF resulted in higher ethanol yields than batch SSF [42,43], whereas other groups found no significant difference in ethanol yield $[39,44]$. One possible explanation of the differences in the observed ethanol yields could be the different experimen- tal methods used. Not only do raw materials and substrate loadings differ between these studies, but the enzyme feeding strategies are also different. Our results suggest that these differences in experimental procedure, such as enzyme feeding strategy and substrate and inhibitor concentrations, could be the reason for the different ethanol yields obtained in these previous studies.

Rudolf et al. [39] reported an increase in initial productivity in fed-batch SSF (all enzymes added in the batch at start-up) compared with batch SSF at a final WIS concentration of $10 \%$, although the overall ethanol yield did not differ significantly. They concluded that the yeast was initially inhibited to a greater degree in batch than in fedbatch SSF; however, the hydrolysis rate was so low that the overall fermentation performance was similar in all experiments. In the present study, a small increase in productivity was observed during the first 4 hours of SSF with a final WIS concentration of $10 \%$ (Figure 4). The initial ethanol productivity was also slightly higher for many of our fed-batch experiments with a final WIS concentration of $14 \%$ (Figure 5, Figure 6), which confirms the results obtained by Rudolf et al. [39]. Another explanation of the increase in initial productivity in fed-batch SSF compared with batch mode could be the improved stirring in fed-batch SSF.

\section{Conclusions}

Running SSF in fed-batch mode does not necessarily give higher ethanol yields than running in batch mode, but when the enzyme-adding method is suitable, similar or slightly higher ethanol yields could be obtained in fedbatch SSF compared with batch mode. The appropriate feeding strategy for the enzymes in fed-batch SSF appears to depend on the conditions during SSF; for example, the WIS and inhibitor concentrations. In the present study, the dependence of ethanol yield on enzyme feeding strategy differed not only with WIS content, but also with inhibitor concentration in experiments with the same WIS content.

Competing interests

The authors declare that they have no competing interests.

\section{Authors' contributions}

$\mathrm{KH}$ planned and carried out the experiments, analyzed the results and wrote the paper. GZ participated in the design of the study, helped analyzing the results and contributed to the draft of the manuscript. MG helped to draft the manuscript. All authors read and approved the final manuscript.

\section{Acknowledgements}

This study was financed by the Swedish National Energy Administration.

\section{Author Details}

Department of Chemical Engineering, Lund University, PO Box 124, SE-221 00 Lund, Sweden

Received: 8 February 2010 Accepted: 25 June 2010

Published: 25 June 2010 


\section{References}

1. Galbe M, Zacchi G: A review of the production of ethanol from softwood. Appl Biochem Biotechnol 2002, 59:618-628.

2. Tengborg C, Stenberg K, Galbe M, Zacchi G, Larsson S, Palmqvist E, et al.: Comparison of $\mathrm{SO}_{2}$ and $\mathrm{H}_{2} \mathrm{SO}_{4}$ impregnation of softwood prior to steam pretreatment on ethanol production. Appl Biochem Biotechnol 1998, 70-72:3-15.

3. Wooley R, Ruth M, Glassner D, Sheehan J: Process design and costing of bioethanol technology: A tool for determining the status and direction of research and development. Biotech Prog 1999, 15:794-803.

4. Gosh P, Pamment NB, Martin WRB: Simultaneous saccharification and fermentation of cellulose: Effect of beta-d-glucosidase activity and ethanol inhibition of cellulases. Enzyme and Microbial Technology 1982, 4:425-430.

5. Takagi M, Abe S, Suzuki S, Emert GH, Yata N: A method for production of alcohol direct from cellulose using cellulase and yeast. Proc Bioconversion Symp, IIT Dehli 1977:551-571.

6. Öhgren K, Bura R, Lesnicki G, Saddler JN, Zacchi G: A comparison between simultaneous saccharification and fermentation and separate hydrolysis and fermentation using steam-pretreated corn stover. Process Biochemistry 2007, 42:834-839.

7. Wingren A, Galbe M, Zacchi G: Techno-economic evaluation of producing ethanol from softwood: Comparison of SSF and SHF and identification of bottlenecks. Biotechnol Progr 2003, 19:1 109-1117.

8. Zacchi G, Axelsson A: Economic evaluation of preconcentration in production of ethanol from dilute sugar solutions. Biotechnology and Bioengineering 1989, 34:223-233.

9. Stenberg K, Bollok M, Reczey K, Galbe M, Zacchi G: Effect of substrate and cellulase concentration of simultaneous saccharification and fermentation of steam-pretreated softwood for ethanol production. Biotechnol Bioeng 2000, 68:204-210.

10. Wright JD, Wyman CE, Grohmann K: Simultanenous saccharification and fermentation of lignocellulose: process evalution. US DOE, Contract no DE-AC02-83CH10093 1987

11. Wyman CE, Spindler DD, Grohmann K: Simultaneous saccharification and fermentation of several lignocellulosic feedstocks to fuel ethanol. Biomass Bioenergy 1992, 3:301-307.

12. Clark TA, Mackie KL: Steam explosion of the softwood Pinus Radiata with sulphur dioxide addition. 1. Process optimisation. J Wood Chem Technol 1987, 7:373-403.

13. Clark TA, Mackie KL, Dare PH, McDonald AG: Steam explosion of softwood Pinus Radiata with sulphure dioxide addition. 2. Process characterization. J Wood Chem Technol 1989, 9:135-166.

14. Dekker RFH: The utilization of autohydrolysis exploded hardwood and softwood for the production of cellulolytic enzymes and fermentable substrates. Biocatalysis 1987, 1:63

15. Elander RT, Dale BE, Holtzapple M, Ladisch MR, Lee YY, Mitchinson C, et al:: Summary of findings from the Biomass Refining Consortium for Applied Fundamentals and Innovation (CAFI): corn stover pretreatment. Cellulose 2009, 16:649-659.

16. Mamers H, Menz DNJ: Explosion pretreatment of Pinus Radiata woodchips for the production of fermentation substrates. Appita 1984, 37:644-649.

17. Puls J, Poutanen K, Viikari L: The effect of steaming pretreatment on the biotechnical utilization of wood components. Bioenergy 1984, 3:173-180

18. Schwald W, Smaridge T, Chan M, Breuil C, Saddler JN: The influence of $\mathrm{SO}_{2}$ impregnation and fractionation on product recovery and enzymic hydrolysis of steam-pretreated sprucewood. Comm Eur Commun 1989:231-242. Enzyme system

19. Olsson L, Hahn-Hägerdal B: Fermentation of lignocellulosic hydrolyzates for ethanol production. Enzyme Microb Technol 1996, 18:312-331.

20. Mes-Hartree M, Saddler JN: The nature of inhibitory materials present in pretreated lignocellulosic substrates which inhibit the enzymatic hydrolysis of cellulose. Biotechnology Letters 1983, 5:531-536.

21. Palmqvist E, Hahn-Hägerdal B, Galbe M, Zacchi G: The effect of watersoluble inhibitors from steam-pretreated willow on enzymatic hydrolysis and ethanol fermentation. Enzyme Microb Technol 1996, 19:470-476

22. Tengborg C, Galbe M, Zacchi G: Reduced inhibition of enzymatic hydrolysis of steam-pretreated softwood. Enzyme Microb Technol 2001, 28:835-844
23. Boyer $L$, Vega $J \mathrm{~L}$, Klasson K, Clausen EC, Gaddy JL: The effects of furfura on ethanol production by Saccharomyces cerevisiae in batch culture. Biomass Bioenergy 1992, 3:41-48

24. Clark TA, Mackie KL: Fermentation inhibitors in wood hydrolysates derived from the softwood Pinus Radiata. J Chem Technol Biotechno 1984, 34B:101-110.

25. Delgenes JP, Moletta R, Navarro JM: Effects of lignocellulose degradation products on ethanol fermentation of glucose and xylose by S. cerevisiae, Z. mobilis, P. stipitis, and C. shehate. Enzyme Microb Technol 1996, 19:220-225.

26. Larsson S, Palmqvist E, Hahn-Hägerdal B, Tengborg C, Stenberg K, Zacchi $G$, et al:: The generation of fermentation inhibitors during dilute acid hydrolysis of softwood - Anion accumulation versus uncoupling. Enzyme and Microbial Technology 1999, 24(3-4):151-159.

27. Linde M, Galbe M, Zacchi G: Simultaneous saccharification and fermentation of steam-pretreated barley straw at low enzyme activity levels and low yeast concentration. Enzyme Microb Technol 2007, 40:1100-1107.

28. Sassner P, Galbe M, Zacchi G: Bioethanol production based on simultaneous saccharification and fermentation of steam-pretreated Salix at high dry-matter content. Enzyme Microb Technol 2006, 39:756-762.

29. Hoyer K, Galbe M, Zacchi G: Production of fuel ethanol from softwood by simultaneous saccharification and fermentation at high dry matter content. Journal of Chemical Technology and Biotechnology 2009, 84:570-577.

30. Olofsson K, Bertilsson M, Lidén G: A short review on SSF - an interesting process option for ethanol production from lignocellulosic feedstocks. Biotechnology for Biofuels 2008, 1:7.

31. Nilsson A, Taherzadeh MJ, Lidén G: Use of dynamic step response for control of fed-batch conversion of lignocellulosic hydrolysate to ethanol. Journal of Biotechnology 2001, 89:41-53

32. Taherzadeh MJ, Niklasson C, Lidén G: Conversion of dilute-acid hydrolyzates of spruce and birch to ethanol by fed-batch fermentation. Bioresource Technol 1999, 69:59-66.

33. Olofsson K, Rudolf A, Lidén G: Designing simultaneous saccharification and fermentation for improved xylose conversion by a recombinant strain of saccharamyces cerevisiae. Journal of Biotechnology 2008, 134:120.

34. Bertilsson M, Olofsson K, Lidén G: Prefermentation improves xylose utilization in simultaneous saccharification and co-fermentation of pretreated spruce. Biotechnology for Biofuels 2009, 2:8.

35. Palmqvist E, Hahn-Hägerdal B, Galbe M, Larsson S, Stenberg K, Szengyel Z, et al:: Design and operation of a bench-scale process development unit for the production of ethanol from lignocellulosics. Bioresource Technol 1996, 58:171-179.

36. Stenberg K, Tengborg C, Galbe M, Zacchi G: Optimization of steam pretreatment of $\mathrm{SO}_{2}$-impregnated mixed softwoods for ethanol production. J Chem Technol Biotechnol 1998, 71:299-308.

37. Taherzadeh MJ, Liden G, Gustafsson L, Niklasson C: The effects of pantothenate deficiency and acetate addition on anaerobic batch fermentation of glucose by Saccharomyces cerevisiae. Appl Microbiol Biotechnol 1996, 46:176-182.

38. Alkasrawi M, Rudolf A, Liden G, Zacchi G: Influence of strain and cultivation procedure on the performance of simultaneous saccharification and fermentation of steam pretreated spruce. $J$ Enzyme Microbial Technol 2006, 38:279-286.

39. Rudolf A, Alkasrawi M, Zacchi G, Lidén G: A comparison of batch and fedbatch simultaneous saccharification and fermentation of steam pretreated spruce. Enzyme Microb Technol 2005, 37:195-204.

40. Sluiter A, Hames B, Ruiz R, Scarlata C, Sluiter J, Templeton D: Determination of structural carbohydrates and lignin in biomass. Laboratory Analytical Procedure, National Renewable Energy Laboratory, Golden, CO, USA; 2005

41. Sluiter A, Hames B, Ruiz R, Scarlata C, Sluiter J, Templeton D: Determination of sugars, byproducts, and degradation products in liquid fraction process samples. Laboratory Analytical Procedure, National Renewable Energy Laboratory, Golden, CO, USA; 2005.

42. Söderström J, Galbe M, Zacchi G: Effect of washing on yield in one- and two-step steam pretreatment of softwood for production of ethanol. Biotechnol Progr 2004, 20:744-749. 
43. Tomás-Pejó E, Olivia JM, González A, Ballesteros I, Ballesteros M: Bioethanol production from wheat straw by the thermotolerant yeast Klyveromyces marximus CECT 10875 in a simultaneous saccharification and fermentation fed-batch process. Fuel 2009, 88:2142-2147.

44. Ballesteros M, Oliva P, Manzanares P, Negro MJ, Ballesteros I: Ethanol production from paper material using a simultaneous saccharification and fermentation system in a fed-batch basis. World J Microbiol Biotechnol 2002, 18:229-261.

doi: 10.1186/1754-6834-3-14

Cite this article as: Hoyer et al., Effects of enzyme feeding strategy on ethanol yield in fed-batch simultaneous saccharification and fermentation of spruce at high dry matter Biotechnology for Biofuels 2010, 3:14

Submit your next manuscript to BioMed Central and take full advantage of:

- Convenient online submission

- Thorough peer review

- No space constraints or color figure charges

- Immediate publication on acceptance

- Inclusion in PubMed, CAS, Scopus and Google Scholar

- Research which is freely available for redistribution

Submit your manuscript at www.biomedcentral.com/submit
C) Biomed Central 